PRZEMYSŁAW OSIEWICZ

Poznań

\title{
Turkey and Its Position on the Cyprus Question Since 1974
}

\section{Introduction}

In case of Turkey its interests in Cyprus date back to the $16^{\text {th }}$ century when armies of Sultan Selim II managed to conquer the island and incorporate it in the Ottoman Empire. As a result, in practice Cyprus had been under the Turkish rule until 1878 when the British took control over the island on the basis of a British-Ottoman treaty. From the legal point of view, however, the period of Ottoman domination finished on the basis of the Treaty of Lausanne of 1923.

After Turks had lost Cyprus for good in 1923 they were not interested in it anymore. At least officially. Despite the fact that they still supported Turkish Cypriots, Mustafa Kemal Atatürk did not intend to gain control over the island at the cost of good relations with the United Kingdom and Greece. The situation changed when it became clear that Greek Cypriots did not want to end their struggle for the unification of Cyprus and Greece, namely enosis.

The Cyprus question has remained one of the most complicated international disputes since $1963 .{ }^{1}$ It was the year when the Republic of Cyprus de facto ceased to exist as a kind of consociational federation. It was a consequence of the intercommunal clashes between 1963-1964 and defeats of Turkish Cypriots. These events caused a kind of national trauma. It was clear that Turkish Cypriots were defenseless without any military and political support of Turkey. Moreover, the Cyprus question became a matter of national interest for Turks. Vamik Volcan claims that "when Turks speak or write about the Cyprus problem they go back to 1963 and recount their horror story when the Greek Cypriots, who outnumbered Cypriot Turks four to one, forced the Cypriot Turks to live in subhuman conditions in enclaves geographically limited to three percent of the island. They lived this way, surrounded by their enemies, for eleven

1 Among recently published books on the Cyprus question are: Michael, S. Michael, Resolving the Cyprus Conflict: Negotiating History, Palgrave Macmillan, Basingstoke 2011; T. Diez, N. Tocci (eds.), Cyprus: A Conflict at the Crossroads, Manchester University Press, Manchester 2009; A. Varnava, H. Faustmann (eds.), Reunifying Cyprus: The Annan Plan and Beyond, I.B. Tauris, London 2009; W. Mallinson, Cyprus: Diplomatic History and the Clash of Theory in International Relations, I.B. Tauris, London 2010; A. Sözen (ed.), The Cyprus Conflict: Looking Ahead, Eastern Mediterranean University Printing House, Famagusta 2008; A. Sepos, The Europeanization of Cyprus: Polity, Policies and Politics, Palgrave Macmillan, Basingstoke 2008; H. A. Richter, A Concise History of Modern Cyprus 1878-2009, Verlag Franz Philipp Rutzen, Ruhpolding 2010; D. Isachenko, The Making of Informal States: Statebuilding in Northern Cyprus and Transdniestria, Palgrave Macmillan, Basingstoke 2012; H. I. Salih, Reshaping of Cyprus: A Two-State Solution, Xlibris, Bloomington 2013. 
years" (Volkan 2008, p. 95). Yet it should be made clear that Greek Cypriots do not share this opinion. Moreover, they claim that such events did not take place and these were Greek Cypriots who became victims of the Turkish invasion of 1974. Consequently, in their opinion the dispute began in 1974, not in 1963.

Although in 50 years there were dozens of peace initiatives all of them were unsuccessful. Harriet Martin rightly points out that "Cyprus has the reputation as a mediator's graveyard and it is easy to see why" (Martin 2006, p. 30). The Cyprus question is not important only to members of both Cypriot communities, namely Greek Cypriots and Turkish Cypriots, but also to Greeks, Turks and the British. There are a few reasons for that including historical background, security issues as well as ethnic composition. In case of Turkey, the Cyprus question is also a matter of national interest.

The article represents a comparative approach. It is dedicated to an analysis of the Turkish foreign policy towards the Cyprus question since 1974, namely after the Turkish military intervention. The given period covers almost 40 years therefore attention is paid to the most significant moments as well as general positions of various Turkish governments on the Cyprus question. The main aim is to determine elements of continuity as well as elements of change within the Turkish position on the dispute. In order to achieve this goal the article has been divided into three main parts, namely (1) historical background, (2) the period between 1974-2002 and finally (3) the period of the Peace and Justice (AKP) rule in Turkey.

\section{A Brief Historical Overview: The Attitude of Turkey Towards the Cyprus Question Before 1974}

The more Greek Cypriots insisted on the unification of Cyprus with Greece, the more Turkey was interested in developments on the island and its future status. The British rule did not pose any threat to Turkey's security. The situation would have changed dramatically if Cyprus had been ceded to Greece. Hence Turkey was determined to react and present its own concept. In the opinion of Sina Akşin, "Turkey had initially laid claim to the whole of Cyprus (with the slogan 'Cyprus is Turkish and will stay Turkish'), but after reassessment it was decided that this was unrealistic and a new demand arose" (Akşin 2007, p. 257). As a result, starting from the mid-50's Turkey opted for a division of the island's territory between Greece and Turkey. Turks introduced even their own term, taksim, to counterbalance the Greek concept, i.e. enosis. Yet none of the above plans was accomplished. In 1959 Greece, Turkey, the United Kingdom as well as representatives of both Cypriot communities made a compromise concerning the future of Cyprus. During the conferences in Zürich and in London all sides agreed on the foundation of an independent Cypriot state. As a result, the Republic of Cyprus was founded in 1960 and Turkey became one out of three guarantors of the constitutional order on the island. Turkey's rights were confirmed in the Treaty of Guarantee of 1960 (Treaty, 2003). Moreover, on the basis of the Additional Protocol No. 1 to the Treaty of Alliance of 1960 Turkey was allowed to maintain up to 650 soldiers on the island. They were to counterbalance the presence of the Greek contingent, namely 950 Greek soldiers (Additional, 2003, p. 136). 
Unfortunately, it soon became clear that the two Cypriot communities were not prepared for cooperation and had different opinions with regard to security issues, power sharing, taxation and the so-called municipal issue. First these differences had led to a constitutional crisis and then resulted in the intercommunal clashes between 1963-64. Although Turkey backed Turkish Cypriots, it did not decide to intervene militarily this time except for a few air raids (Oberling 1982, p. 119). Turkish Cypriots left all public posts and were forced to live in a number of small enclaves scattered all over the island. As living conditions in the enclaves were very bad, Turkey was helping Turkish Cypriots within bounds of possibility. Simultaneously, Turks engaged in a diplomatic campaign in order to support Turkish Cypriots. Despite that, another crisis on the island took place in 1967. According to Cihat Göktepe "the 1967 Cyprus crisis brought both Turkey and Greece to the edge of war. Turkey was determined to send troops to the island with the intention to protect her interests and the security of Turkish Cypriots. This problem was solved in a peaceful way. The Americans were very active in this process" (Göktepe 2005, p. 441). But unsettled disputes remain unsettled disputes. The intervention had taken place neither in 1964 nor in 1967, but in 1974 it was simply unavoidable. And there were a few reasons for that.

The successful coup d'état of the Greek Cypriot right of 15 July 1974 radically changed the situation on the island. Turkey had two options. The first one was connected with diplomatic efforts, while the second meant a military intervention. It was not a secret that the Turkish armed forces were well prepared for such scenario. First Prime Minister Bülent Ecevit decided to search for a peaceful solution in the UK, albeit the army was ready for landing. When diplomatic talks did not meet Turkey's expectations, the Turkish government decided to authorize the beginning of the military operation on 20 July.

Umut Uzer rightly pointed out that "the 1974 intervention in Cyprus was a case of the military and the government coordinating their policies in a diligent manner. In fact, because there had been indirect military rule in the years between 1971 and 1973, which had exposed the army to the game of politics and left it with little taste for it thereafter, the military was reluctant to influence governmental policies. The successful conclusion of the Cyprus debacle increased the military establishment's confidence in the Ecevit government in particular and in civilian rule in general" (Uzer 2011, p. 78).

Although the Turkish military intervention in Cyprus was condemned by the international community especially the United Nations Security Council, the Turkish authorities claimed that they had no other choice but to intervene. The Turkish government's priority was to protect the Turkish Cypriot community at any cost. The then Prime Minister Bülent Ecevit never changed his opinion about legitimacy of the 1974 military operation. In 2000, in an interview with Johann Pillai, Ecevit said: "But Turkey - we - cannot give up our national rights... and we keep reminding our European friends that there is no real problem on the island; on the contrary, before the present setup was established in 1974, there was continuous bloodshed on the island, either in the form of genocidal attacks against the Turks, or as conflicts between Greek factions. But since mid-1974, mid-August 1974, there has existed complete, uninterrupted peace on the island for the first time" (Pillai, 2000, p. 21). 


\section{Turkey and Its Position on the Cyprus Question Between 1974-2002}

One of the consequences of the intervention has been a de facto division of the island. De iure exists only one Cypriot state, namely the Republic of Cyprus, however, de facto there are two of them. In November 1983 Turkish Cypriots unilaterally declared independence and foundation of the Turkish Republic of Northern Cyprus (TRNC). So far the new realities on the island have been recognized only by Turkey which maintains diplomatic relations with the TRNC. Turkey is also burdened with the Turkish Cypriot budget. Annually Turkey guarantees and transfers money which covers around a half of the TRNC's budget.

According to Philip Robins, in the 90's the Cyprus question became the most important issue of the Turkish foreign policy. He claimed that the general lack of public mobilization, for instance, "in the Bosnian case was hardly surprising given the elite orientation of foreign policy in Turkey, and the absence of issues other than Cyprus that animate the wider population" (Robins, 2003, p. 369). In the given period the Cyprus question was also important as an element of the Greek-Turkish relations. Tensions between Athens and Ankara made quite an impact on the situation on the island.

Besides, the unsettled Cyprus problem also determined EU-Turkey relations. "The irritations on both sides reached a high-point in 1997. After the EU had yet again urged Turkey to find a solution to the Cyprus question, to improve its human rights record and to ameliorate conditions in Kurdish areas, the Turkish minister of foreign affairs [Tansu] Çiller threatened to block the NATO membership of Poland, Hungary and the Czech Republic unless Turkey was also given the status of candidate-member of the EU" (Brusse, Griffiths 2004, p. 23-24).

At that time the Turkish position meant unconditional support for Turkish Cypriots especially for the then President of the Turkish Republic of Northern Cyprus Rauf Denktaş. Until 2002 Turkish governments did not intend to compromise their stances on the Cyprus question for the sake of being accepted by the European Union. Moreover, some Turkish politicians blamed both the European Union and Greek Cypriots for a stalemate in the intercommunal negotiation process at the turn of the century. The reason was the opening of accession talks between the EU and the Republic of Cyprus, namely only with the Greek Cypriot side. Turkey was afraid that Turkish Cypriots would become marginalized. Besides, once the Republic of Cyprus became an EU member state, it would be able to block the potential accession process of Turkey. One of these politicians was Ismail Cem, the former Minister of Foreign Affairs of Turkey, who in 1996 forewarned against consequences of a possible accession of the Republic of Cyprus to the European Union. In one of his speeches Cem stated as follows: "Greek Cypriots are quite satisfied with the status quo. They are encouraged by the European Union, which admitted them as a 'candidate' for accession. They think that sooner or later they will become a member and have the advantage of making integral part to a powerful union. Then, they figure, they will be in a much stronger position to dictate their will to Turkish Cypriots. Therefore, they do not want any change, they are not after a mutually acceptable solution, and they just want the time to run by" (Cem, 2001, p. 143).

In 2000 Wojciech Forysiński wrote: "There are two other political conditions for Turkey which go beyond the Copenhagen criteria, or at least beyond the normal under- 
standing of the Copenhagen criteria. These are the Cyprus question and settlement of outstanding border disputes" (Forysiński, 2000, p. 200). In addition he underlined that Turkey seemed to have no intention to change its position on Cyprus and maintained that the European Union's policy did not in any way enhance the chances of a settlement. It made it only more difficult to achieve (Forysiński, 2000, p. 201). Undoubtedly, such assessment was right at that time. One could say a lot about the Turkish foreign policy towards Cyprus between 1974-2002, but not that it was flexible or conciliatory. Nonetheless, at the very beginning of the $21^{\text {st }}$ century some Turkish politicians understood the necessity of a realignment of the Turkish foreign policy. Among them were future leaders Recep Tayyip Erdoğan, Abdullah Gül and Ahmet Davutoğlu. The outlook of the last of them was of primary meaning.

\section{The Reorientation in the Turkish Foreign Policy Under the AKP Rule: Implications for the Cyprus Question}

The Turkish foreign policy has undergone significant changes since November 2002 when the Peace and Justice Party (AKP) came into power in Turkey. The Copenhagen Summit of December 2002 "showed clearly that the possibility of Turkey's accession to Europe depends on the resolution of the Cyprus conflict" (Keyman, Öniş, 2007, p. 172). Yet it was easy to say, hard to conduct. Nonetheless, the AKP government was determined to conduct such changes. Recep Tayyip Erdoğan publicly stated, "as an indication of his determination to solve the Cyprus problem, that Turkey would be always one step ahead in coming up with proposals so as to find breakthroughs in the resolution of the problems" (Kibaroğlu and Kibaroğlu, 2009, 144). The opposition harshly criticized the new government for such fundamental changes. At the same time AKP presented such shift as an outcome of rational choice and an example of pragmatism. This way the government intended to get rid of ideological limitations especially of nationalistic nature which had been promoted before, for instance, by the army and kemalists.

A Turkish scholar and politician, Ahmet Davutoğlu, became the main author of a new concept of foreign policy. His views and the concept of so-called strategic depth were first presented in the book entitled 'Startejik derinlik: Türkiye'nin uluslararas? konumu' (Davutoğlu, 2012). One of the most important elements of the new foreign policy was connected with a new concept, namely zero problems with neighbours policy. Its main aspect was elimination of all disputes and normalization of bilateral relations with all neighbouring countries including Cyprus.

The change of position on the Cyprus question seemed to be necessary in order to facilitate dialogue with the European Union and open accession negotiations. It was almost certain that any continuation of the hard line meant no progress. Although AKP was in favour of such change, such stance was being criticized by other parties. For instance, Mümtaz Soysal, the former Minister of Foreign Affairs of Turkey, wrote in one of his articles: "I am not against a solution to the Cyprus Problem. But we should insist on a solution that neither suppresses the Turkish population nor disregards Turkey's rights as a guarantor state and its legitimate concerns over the island. It is unacceptable 
to grant England the right to have a military base on Cyprus and deny Turkey the right to protect her interests by military means if necessary. This is not an acceptable solution. Therefore, when we sit at the negotiating table with our European counterparts, we should stand up for our neglected rights and prerogatives" (Soysal, 2002, p. 351).

From the beginning of the AKP rule in Turkey it was clear that Turkish Cypriot leader Rauf Denktaş lost unconditional political support of Ankara. He could, however, still count on the army and President Ahmet Necdet Sezer. Unfortunately, as a hard-liner, Denktaş had nothing new to offer and became a kind of burden for the new foreign policy of Turkey. Undoubtedly, it was one of the reasons for supporting Mehmet Ali Talat and his Republican Turkish Party during the parliamentary elections in the TRNC in December 2003. This way Recep Tayyip Erdoğan intended to present a conciliatory gesture, resume intercommunal talks and, as a result, remove the biggest obstacle in EU-Turkey relations. The later resumption of talks and the April 2004 referenda in Cyprus only proved that Erdoğan's tactic was right. Although the so-called Annan Plan had not been approved by both Cypriot communities, Turkey was praised for its constructive approach towards the Cyprus question. The Turkish government had encouraged Turkish Cypriots to accept the plan and it was the Greek Cypriot side which turned it down. In terms of public relations, the 2004 referenda were meant a big success of Turkey and the Turkish Cypriot community. One may even say that it was one of the main reasons for the opening of accession negotiations with Turkey on 3 October 2005.

Yet the new tactic appeared to be only partially successful. Turkey also demanded lifting the de facto isolation of northern Cyprus. The isolation is both political and economic. It became tiresome especially after the foundation of the Turkish Republic of Northern Cyprus in 1983. Top Turkish politicians kept supporting Turkish Cypriots and criticizing the EU at the same time. For example, Egemen Bağış, the Turkish Minister for European Union and Chief Negotiator, wrote: "On Cyprus, we expect EU member states to act in full awareness of their commitments. The Council decision of April 26, 2004, regarding lifting the isolation of northern Cyprus has not yet been implemented. The direct trade regulation has not been adopted. It is particularly sad that Turkish-EU relations should be held hostage by a single member's selfish interest. It is unfortunate that large member states are hiding behind the island" (Bağış 2011, p. 34).

In 2006 Turkey presented its own peace initiative known as the Action Plan. Its main assumptions were outlined by the then Minister of Foreign Affairs Abdullah Gül. These were:

- "Opening of the sea ports of Turkey to Greek Cypriot vessels serving the trade of goods in accordance with the EC-Turkey Customs Union;

- Allowing Greek Cypriot air carriers to use the Turkish air space for over-flights and to land at the Turkish airports in accordance with relevant international rules and procedures;

- Opening of the ports in North Cyprus, including Gazimağusa, Girne, and Gemikonağı to international traffic of goods, persons and services under Turkish Cypriot management;

- Opening of Ercan airport for direct flights under the Turkish Cypriot management;

- Special arrangements for the practical inclusion of North Cyprus, as an economic entity, into the European Union's customs union. Unhindered direct trade between both sides of the Island as well as with the outside world; 
- Participation of the Turkish Cypriot side in international sports, cultural and other social activities" (Gül 2006).

The above initiative was not implemented, however, it was a clear sign of goodwill and readiness for cooperation. Again lack of trust became the main reason for the failure of the Action Plan. The Greek Cypriot community was afraid of lifting the restrictions imposed on Turkish Cypriots. The authorities of the Republic of Cyprus claimed that if they allowed, for example, to open the ports and airports in 'the occupied territories', Turkish Cypriots would lose motivation to resume bilateral talks. Moreover, Greek Cypriots would gain almost nothing, but they would be forced to change their attitude towards the Cyprus question completely. It should be emphasized that such claims were partially true, because the Action Plan was not well balanced and offered Turkish Cypriots much more than Greek Cypriots. Nonetheless, the plan still represents a good example of expectations of the Turkish side. It's a kind of minimum plan to be achieved by Turkish Cypriots and Turkey in a course of any bilateral negotiations.

The AKP government supports the ongoing negotiation process on the island which was initiated in 2008. Turkey had backed first Mehmet Ali Talat, the former President of the TRNC and the Turkish Cypriot leader, and then, after the 2008 Turkish Cypriot presidential elections, it gave its support to Talat's successor Derviş Eroğlu. Just as the Turkish Cypriot leadership Turkey blames the Greek Cypriot side for no progress during the current round of talks. In practice the negotiations were suspended due to presidential elections in the Republic of Cyprus and the Cypriot Presidency of the Council of the European Union in the second half of 2012. It seems that such developments suit both sides. Nevertheless, the talks are to be resumed in October 2013 (Transcript, 2013).

Baskin Oran claims that "looking back at a decade of AKP majority rule, it appears that most of Turkey's chronic problems have evaded treatment. Domestically, the Kurdish issue remains far from any resolution. Internationally, next to no progress has been made on Cyprus or with regards to relations with Armenia and Armenian claims for genocide recognition" (Oran, 2012, p. xxii). Such observation is true as far as the Cyprus question is concerned. Despite the more flexible attitude of the AKP dominated government one cannot observe many positive results. Probably the most noticeable outcome was the opening of checkpoints on the island in 2003. And that's it.

No doubt the Cyprus question remains the most important matter of the Turkish foreign policy. The best proof is that the dispute tops the main issues of the foreign policy on the official website of the Ministry of Foreign Affairs (Main, 2013). Besides, the Cyprus question is also very important to public opinion. Although Turkey presents the Cyprus question as an external issue and recognizes the TRNC as a sovereign state, there is a direct link between developments on the island and political situation in Turkey. Hence all Turkish governments, including the current government dominated by AKP, have to take it into consideration. Every declaration, every concession or decision are carefully analyzed in order to save the national consensus. As a matter of fact, almost all Turkish political parties share the opinion that Cyprus constitutes an element of the Turkish sphere of influence and that control over it is of vital importance from the geostrategic point of view. Therefore one can say that the main objectives have been invariable since 1974 and there have been only different ideas concerning ways of fulfilling the objectives. As Kıvanç Ulusoy claims, "for Turkey, the Cyprus problem has not 
been an ordinary foreign policy issue since its inception. Defined as a 'national cause', it had clear repercussions on the power struggle in Turkey between the parties of status quo and change in domestic politics and foreign policy" (Ulusoy, 2008, p. 313-314).

\section{The Cyprus Imbroglio: Implications for Turkey}

In the 2003 EU Commission Progress Report, "the European Commission has warned that the absence of a settlement could become a serious obstacle to Turkey's aspirations of starting formal accession talks with the European Union. For the first time a direct link was established in an EU report between the resolution of the Cyprus problem and the starting of negotiations with Turkey" (Y1lmaz, 2004, p. 130). As a consequence, Turkey modified its stance on the Cyprus question and supported the Annan Plan. Although the UN initiative did not come into force, Turkey managed to strengthen its position and open the accession negotiations with the EU in 2005. Unfortunately, it was the last good news for Ankara. The talks were proceeding very slowly. Within eight years both sides provisionally closed only one out of 35 chapters. One of the reasons is the 2006 decision of the EU which froze talks in eight key areas under negotiation due to the unsettled Cyprus question and lack of bilateral diplomatic relations between the Republic of Cyprus and Turkey. "Turkey refused to extend the Additional Protocol to the Ankara Agreement to Cyprus. Turkey did in fact not open ports and airports to Cypriot vessels, because the isolation of northern Cyprus, which the EU was supposed to ease, continued, despite the Turkish Cypriot yes vote" (Öktem, 2011, p. 140). Hence at the moment the EU-Turkey accession negotiations depend mainly on the progress in bi-communal talks and normalization of relations between Turks and the Republic of Cyprus. The only question is if Turkey was ready to sacrifice Cyprus for the sake of EU membership. Nowadays it would be very hard to imagine such progress of events. No Turkish government would take a risk of a complete withdrawal from the island as it is regarded as a national interest by the majority of citizens. One could even say that for Turks the Cyprus question has become a kind of affair of honor. Any significant concessions would be interpreted as signs of weakness.

According to Özlem Oğuz Çilsal, Praxoula Kyriacou and Fiona Mullen, "the largest opportunity, however, comes from opening up Turkey's potential as an energy hub. As a direct by-product of the Cyprus problem, Turkey has been unable to open the energy chapter in its accession negotiations with the EU and this kind of uncertainty deters investors. On the other hand, a settlement of the Cyprus problem that reunites the island and brings peace and stability to the Turkey-Cyprus-Greece region would vastly increase foreign interest in the energy sector" (Çilsal, Kyriacou, Mullen, 2010, p. 2). It should be emphasized, however, that there is no proof that potential investors hesitate to invest in the Turkish energy sector due to the unsettled Cyprus question. Yet in the future Turkey might, for instance, derive money from transit of Cypriot gas. At the moment it is impossible because of political limitations. But if the Cyprus dispute was settled, such solution would be mutually desirable and beneficial.

The most difficult consequence for Turkey, however, is connected with a kind of paradoxical stalemate. On the one hand it is hard to imagine Turkey as an EU member 
state without any prior settlement of the Cyprus question, but on the other hand it is highly unlikely that the Cyprus dispute will be settled without a prior accession of Turkey to the EU. The more time is passing, the worse. Turkish public opinion is less and less interested in an EU membership for Turkey (Çaha, 2011). Such scenario cannot be beneficial to any side of the dispute. In the opinion of Ahmet Sözen, "a Turkey slipping away from the EU will have less motivation to undertake further reforms in the area of democracy; it will have less incentive to solve the Cyprus problem; and it will fail to become a model of consensus of civilizations" in the post-September 11 era, as well as a democratic model for the post-Arab Spring Middle Eastern and North African states, which will be a great loss for the international community at large" (Sözen, 2012, p. 125).

\section{Conclusions}

The Cyprus question has been one of the key aspects of the Turkish foreign policy since the 1950's. Yet its role became evident after the 1974 events. It was the moment when Turkey engaged directly in the Cyprus question. Since then all consecutive Turkish governments have been burdened with the Cyprus problem and its bilateral as well as regional consequences. They have two dimensions, namely internal as well as external. The first dimension affects the Turkish political stage, while the second dimension affects EU-Turkey relations as well as Turkey-TRNC relations and, finally, Turkey-the Republic of Cyprus relations.

As far as the Turkish tactic on the Cyprus question is concerned, one could observe a significant change in 2002 when the Peace and Justice Party came into power. Yet the main aims remained unchanged. The AKP government took a more flexible stand in order to prove its goodwill and improve its bilateral relations with the European Union. The Greek Cypriot side remained skeptical with reference to the Turkish goodwill, but the fact is that Ankara was trying to convince Turkish Cypriots to accept the Annan Plan in 2004 and bring the 30 years old division of the island to an end. Although the Annan Plan did not come into force due to a resounding 'no' of Greek Cypriots, the Turkish tactic was successful as Turkish Cypriots accepted the plan. As a result, nobody could accuse Turkey of inaction or obstruction of negotiations anymore. This time it was the Greek Cypriot side which was to blame. Undoubtedly, the new policy paved the way for the opening of EU-Turkey negotiations in October 2005.

One can say that the main objectives have been invariable since 1974, there have been only different ideas concerning ways of fulfilling the objectives. For instance, in terms of official rhetoric the AKP position is more flexible than the position of CHP, but what both parties have in common is that they want Turkey and Turkish Cypriots to gain as much as possible without any serious concessions. The reason is the Cyprus question still remains the most important issue of the Turkish foreign policy. What's more, it is also a national cause with all its impacts on the power struggle in Turkey. No matter who is in power, there are some concessions which will never be made, e.g. a complete withdrawal of Turkish troops from the island. As a result, both the European Union and Greek Cypriots can expect a constructive approach of Turkey to the Cyprus problem, albeit it has its serious political limitations. 


\section{References}

Additional Protocol No. 1 to the Treaty of Alliance of 1960 (2003), in: The 1960 Treaties on Cyprus and Selected Subsequent Acts, (ed.) N. D. Macris, Bibliopolis, Mannheim-Möhnsee.

Akşin S. (2007), Turkey From Empire to Revolutionary Republic: The Emergence of the Turkish Nation from 1789 to Present, Hurst \& Company, London.

Bağış, Egemen (2011), State of play in Turkish-EU ties: Turkey remains firm on EU path, "Turkish Review", 1:2, p. 34-39.

Brusse W. A., Griffiths R. T. (2004), Good Intentions and Hidden Motives. Turkey-EU Relations in a Historical Perspective, in: Turkey and the EU Enlargement. Processes of Incorporation, (eds.) R. T. Griffiths, D. Özdemir, Istanbul Bilgi University Press, Istanbul.

Çaha Ö. (2011), The EU, foreign policy and the new government, http://www.turkishreview.org/ tr/newsDetail_getNewsById.action?sectionId=343\&newsId=223174, accessed on 8 August 2013.

Cem I. (2001), Turkey in the New Century, Rustem Publishing, Nicosia.

Çilsal Ö. O., Kyriacou P. A., Mullen F. (2010), The Day After III: The Cyprus Peace Dividend for Turkey and Greece, PRIO Cyprus Centre, Nicosia.

Davutoğlu A. (2012), Startejik derinlik: Türkiye'nin uluslararas? konumu, Küre Yayınları, Istanbul.

Forysiński W. (2000), Enlargement of the European Union: Accession Conditions for Turkey, in: Turkey in the $21^{\text {st }}$ Century: Changing Role on World Politics?, (eds.) M. Tahiroğlu, T. Y. Ismael, Eastern Mediterranean University Press, Gazimağusa.

Göktepe C. (2005), The Cyprus Crisis of 1967 and Its Effects on Turkey's Foreign Relations, "Middle Eastern Studies", 41:3, p. 431-444.

Gül A. (2006), New Initiative by Turkey on Cyprus, http://www.mfa.gov.tr/new-initiative-by-turkey-on-cyprus.en.mfa, accessed on 6 August 2013.

Keyman E. F., Öniş Z. (2007), Turkish Politics In a Changing World: Global Dynamics and Domestic Transformations, Istanbul Bilgi University Press, Istanbul.

Kibaroğlu M., Kibaroğlu A. (2009), Global Security Watch - Turkey: A Reference Handbook, Praeger Security International, Westport.

Luke H. C. (1921), Cyprus Under the Turks 1571-1878: A Record Based on the Archives of the English Consulate in Cyprus Under the Levant Company and After, Oxford University Press, Oxford.

Main Issues (2013), Republic of Turkey. Ministry of Foreign Affairs, http://www.mfa.gov.tr/ sub.en.mfa?395d59f6-c33c-4364-9744-cff90ec18a3e, accessed on 6 August 2013.

Martin H. (2006), Kings of Peace, Pawns of War: The Untold Story of Peace-making, Continuum, London.

Oberling P. (1982), The Road to Bellapais: the Turkish Cypriot Exodus to Northern Cyprus, Columbia University Press, New York.

Oran B. (2012), Preface: A Proactive Policy with Many Hunches on the Back, in: Another Empire? A Decade of Turkey's Foreign Policy Under the Justice and Development Party, (eds.) K. Öktem, A. Kadıoğlu, M. Karlı, Istanbul Bilgi University Press, Istanbul, p. xv-xxiii.

Öktem K. (2011), Turkey Since 1989: Angry Nation, Zed Books, London.

Pillai J. (2000), A Conversation with Mr. Bülent Ecevit, the Prime Minister of the Republic of Turkey, "Journal of Cyprus Studies", 5:3-4, p. 9-76.

Robin P. (2003), Suits and Uniforms: Turkish Foreign Policy Since the Cold War, Hurst \& Company, London. 
Soysal M. (2002), The Cyprus Problem and Turkey's Candidacy to EU Membership, in: The European Union Enlargement Process and Turkey, (eds.) M. Dartan, Ç. Nas, Marmara University European Community Institute, Istanbul.

Sözen A. (2012), Heading Towards the Defining Moment in Cyprus: Public Opinion vs Realities on the Ground, "Insight Turkey", 14:1, p. 109-129.

Transcript of media encounter with Alexander Downer, Special Adviser of the Secretary-General following his meeting with Greek Cypriot Leader Nicos Anastasiades, 30 July 2013 (2013), United Nations Good Offices Mission, http://www.uncyprustalks.org/nqcontent.cfm?a_id= $5455 \& \mathrm{tt}=$ graphic\&lang=11, accessed on 8 August 2013.

Treaty of Guarantee of 1960 (2003), in: The 1960 Treaties on Cyprus and Selected Subsequent Acts, (ed.) N. D. Macris, Bibliopolis, Mannheim-Möhnsee.

Ulusoy K. (2008), The Europeanization of Turkey and Its Impact on the Cyprus Problem, "Journal of Southern Europe and the Balkans", 10:3, p. 309-329.

Uzer U. (2011), Identity and Turkish Foreign Policy: The Kemalist Influence in Cyprus and the Caucasus, I.B. Tauris, London.

Volkan V. (2008), Trauma, Identity and Search for a Solution in Cyprus, "Insight Turkey”, 10:4, p. $95-110$.

Y1lmaz Ş. (2004), The Thorny Path: Turkey-EU Relations in Perspective, "Journal of Cyprus Studies", 8-9:22-25, p. 126-135.

\section{Summary}

The Cyprus question is one of the most complex international disputes, which the Republic of Turkey has been engaged in since its foundation in 1923. Although Cyprus was conquered by the Ottoman Empire in 1571, the Turks actually lost control over the island in 1878. British rule only strengthened ethnic divisions in Cyprus, especially when Cyprus became a Crown Colony in 1925. After World War II, Greek Cypriots wanted to unite with mainland Greece (enosis), while Turkish Cypriots promoted the division of the island's territory between Greece and Turkey (taksim). Finally, both sides agreed on the foundation of an independent Cypriot state, named the Republic of Cyprus, in 1960, and became its guarantors. Yet this was not the end of the Cyprus question. Lack of mutual trust led to further clashes between the two communities in 1963 and resulted in a disintegration of the state. The most important events, however, took place in 1974, when Turkey decided to intervene militarily on the island in response to a Greek Cypriot coup d'état. This paper is devoted to the Turkish position on the Cyprus question after the intervention and division of Cyprus. Has the policy undergone any significant changes since 1974? Is the Cyprus question a matter of Turkish national interest? The paper compares two periods, namely that from 1974 to 2002 and after 2002 .

\section{Streszczenie}

\section{Turcja i jej stanowiska w kwestii Cypru od 1974 roku}

Kwestia cypryjska pozostaje jednym z najbardziej złożonych sporów międzynarodowych, w który Republika Turcji jest zaangażowana od początków swego funkcjonowania, czyli roku 1923. Cypr został podbity przez Imperium Osmańskie w 1571 roku. Turcy stracili jednak nad nim faktyczną kontrolę w 1878 roku. Okres brytyjskich rządów przyczynił się do zaostrzenia po- 
działu etnicznego na wyspie, zwłaszcza po tym, gdy w 1925 roku Cypr został ogłoszony kolonią. Po II wojnie światowej Greccy Cypryjczycy nadal chcieli doprowadzić do zjednoczenia z kontynentalną Grecją (enosis), podczas gdy Tureccy Cypryjczycy i Turcja opowiadali się za podziałem terytorium wyspy pomiędzy Grecję i Turcję (taksim). Ostatecznie obie strony przystały na rozwiązanie kompromisowe - utworzenie niepodległej Republiki Cypryjskiej w 1960 roku. Grecja i Turcja stały się wówczas państwami gwarantami ładu konstytucyjnego na wyspie. Jednakże, jak się miało wkrótce okazać, przyjęte rozwiązania nie oznaczały końca problemu. Deficyt wzajemnego zaufania doprowadził do starć pomiędzy członkami obu cypryjskich społeczności i, będącej ich konsekwencją, faktycznej dezintegracji państwa w 1963 roku. Niemniej, najistotniejsze wydarzenia miały miejsce w roku 1974, gdy turecki rząd podjął decyzję o przeprowadzeniu interwencji zbrojnej w odpowiedzi na prawicowy zamach stanu. Niniejszy artykuł poświęcony jest stanowisku Turcji w sprawie Cypru w okresie po interwencji i w warunkach faktycznego podziału wyspy na dwa państwa. Czy po 1974 roku stanowisko Turcji ulegało znaczącym modyfikacjom? Czy kwestia cypryjska stanowi turecki interes narodowy? Podstawę analizy stanowi podział i porównanie polityki tureckiej w dwóch okresach: 1974-2002 oraz po 2002 roku. 